\title{
Hezbollah: The Global Footprint of Lebanon's Party of God. By Matthew Levitt, Ph.D. Washington, D.C.: Georgetown University Press, 2013. ISBN 978-1-62616-013-2. Bibliography. Sources cited. Index. Pp. xv, 407. \$32.95.
}

Mark Roberts

Transportation Security Specialist

Follow this and additional works at: https://digitalcommons.usf.edu/jss

pp. 109-111

\section{Recommended Citation}

Roberts, Mark. "Hezbollah: The Global Footprint of Lebanon's Party of God. By Matthew Levitt, Ph.D. Washington, D.C.: Georgetown University Press, 2013. ISBN 978-1-62616-013-2. Bibliography. Sources cited. Index. Pp. xv, 407. \$32.95.." Journal of Strategic Security 6, no. 4 (2013) : 109-111. DOI: http://dx.doi.org/10.5038/1944-0472.6.4.8 Available at: https://digitalcommons.usf.edu/jss/vol6/iss4/8

This Book Review is brought to you for free and open access by the Open Access Journals at Digital Commons @ University of South Florida. It has been accepted for inclusion in Journal of Strategic Security by an authorized editor of Digital Commons @ University of South Florida. For more information, please contact digitalcommons@usf.edu. 
Hezbollah: The Global Footprint of Lebanon's Party of God. By Matthew Levitt, Ph.D. Washington, D.C.: Georgetown University Press, 2013. ISBN 978-1-62616-013-2. Bibliography. Sources cited. Index. Pp. xv, 407. \$32.95. 


\section{Hezbollah: The Global Footprint of Lebanon's Party of God. By Matthew Levitt, Ph.D. Washington, D.C.: Georgetown University Press, 2013. ISBN 978-1-62616-013-2. Bibliography. Sources cited. Index. Pp. xv, 407. \$32.95.}

Until the terrorist attacks of September 11, 2001, Hezbollah was responsible for more U.S. deaths due to terrorism than any other terrorist group. While the U.S. Government has focused much of its counterterrorism efforts on al-Qa'ida in the last 12 years, Dr. Matthew Levitt makes is abundantly clear in his new masterpiece that Hezbollah is still a potent force to be reckoned with or ignored at extreme peril.

Levitt is a senior fellow and Director of the Washington Institute for Near East Policy's Stein Program on Counterterrorism and Intelligence. He has served in various terrorism analysis positions in the U.S. Government and academic and policy institutions. He previously authored a book on the Palestinian terrorist group Hamas.

Levitt's book is both authoritative and compelling. His skillful writing style gives us a book that reads like a fast-paced, heart pounding techno-thriller, enthralling the reader, who can't turn the pages fast enough. His research is meticulous, encompassing scores of unimpeachable sources ranging from recently declassified documents that shed new light on previously occluded analysis and information to myriad interviews to various legal documents.

Weaving his tapestry with consummate skill, the author guides the reader through Hezbollah's history, structure, driving philosophy, terrorist and counterintelligence tradecraft, and savvy business acumen. Throughout the book he demonstrates the worldwide scope, range, and capabilities of one of the world's most lethal terrorist organizations.

Forged in the wake of the Iranian revolution during civil war in Lebanon and conflict with Israel, Hezbollah was sponsored by Iran to help bolster and defend Lebanon's Shi' a majority in the early 1980s. With early ties to Iran's Islamic Revolutionary Guard Corps (IRGC) and Ministry of Intelligence and Security (MOIS), Hezbollah received funding, training in radical Muslim ideology, weapons and tactics, terrorism and counterintelligence tradecraft, and explosives. The group established itself in Lebanon with embassy bombings, kidnappings, assassinations, hijackings, and the U.S. Marine barracks attack (which was the largest non-nuclear explosion since World War II). Its capture, torture, and murder of a CIA Station Chief crippled U.S. intelligence efforts in Lebanon for years. The brutal TWA 847 hijacking is still used as a case study for aviation security and terrorism. The group also carried out many successful terrorist operations in Kuwait, a key U.S. ally in the Persian Gulf.

Hezbollah went on to carry out numerous, high-profile assassinations of Iranian dissidents throughout Western Europe, flagrantly killing ex-patriots in France, England, Austria, Switzerland, and Germany. It also established networks in Europe through Muslim communities, using them as cover to carry out fund-raising and propaganda.

In Latin America, the group has a well-entrenched presence in numerous countries. Levitt describes in fascinating detail how the group bombed the Israeli embassy in Buenos Aires, Argentina in 1992 and then carried out a devastating attack on the Argentine-Israeli Friendship 
Society (AMIA) two years later. He outlines the depth and breadth and scope of their activities in the Tri-Border Region (TBR) between Argentina, Brazil, and Paraguay. In the TBR, Hezbollah engages in terrorism, counterfeiting, black marketeering, arms and drug smuggling, document fraud, money laundering, and human trafficking — with impunity. Working with the IRGC and MOIS, Hezbollah conducts business with Colombian drug lords, moving narcotics and laundered currency between Lebanon's Bekka Valley and Latin America. Using springboards in Mexico and Venezuela, Hezbollah uses forged passports with Hispanic identities to fraudulently enter the U.S.

Levitt outlines the scope of Hezbollah activities in Southeast Asia, demonstrating operational and financial cells in Thailand, the Philippines, Singapore, Malaysia, and Indonesia, to name but a few. The organization uses Southeast Asia as a recruiting and logistics hub.

The range and presence of Hezbollah activity in North America is truly unsettling. Operating a sophisticated and highly lucrative tax-evading tobacco running scheme, the organization has criminal and terrorist ties worthy of a white knuckle action movie. Moving untaxed tobacco from North Carolina to Michigan provides a solid business plan and infrastructure to also engage in money laundering, racketeering, wire fraud, conspiracy, visa and marriage fraud, fund raising, internet pornography, drug trafficking, counterfeit Viagra (made in China) sales, and material support to terrorism. After numerous traffic stops due to Middle Eastern males speeding along the Interstate, the groups used evolving tradecraft. It now uses white women driving minivans with bike racks on top to give the appearance of a family vacation. Crossing between the U.S. and Canada, Hezbollah engages in arms trafficking, fund raising, and propagation of charity front companies.

Levitt's blow-by-blow description of the 1996 Khobar Towers attack in Dhahran, Saudi Arabia is riveting. He outlines how the operation was conceived and planned between Hezbollah, the MOIS, and the IRGC. The intra-agency coordination and movement of personnel and materiel shed new insight on how the attack was carried out. In parallel fashion, he portrays how the U.S. perceived the series of events leading up to the attack and how events unfolded it.

Levitt's treatment of Hezbollah's anti-Israel focus is penetrating and comprehensive. He shows the depth of the group's materiel and financial support to fellow terrorist groups Hamas and Palestinian Islamic Jihad. As Israeli authorities cracked down on ethnic Arab operatives from the Levant, the group recruited light skinned operatives moving through Europe using false travel documents.

Africa is a focal point for finance and logistics. The group operates in the Horn of Africa, West Africa and anywhere an ethnic Lebanese community exists. Using mafia-style "shakedown" techniques, Hezbollah taps the Lebanese ex-patriot communities in Africa to finance cover companies, tax fraud, money laundering, blood diamond transactions, recruiting, arms smuggling, and narcotics trafficking.

Hezbollah partnered with the IRGC and the MOIS to carry out anti-U.S. operations in Iraq: Hezbollah trained and equipped Shi' a militants to attack U.S. forces. Enacting an agenda from the Iran-Iraq War (1980-1988), Hezbollah serves as an Iranian surrogate in a proxy war seeking 
to further Iranian influence among Iraq's Shi'a majority. In so doing, Iran uses Hezbollah to reshape Iraq and expand its regional influence. Hezbollah backs multiple, sometimes opposing factions to foment instability, further Iranian interests, and push the U.S. out of the region. This was a clear replication of the strategy Hezbollah and Iran used in Lebanon to drive out U.S. forces 30 years ago.

Levitt's book is at present the definitive book on Hezbollah and should be required reading for anyone working Iran or Hezbollah issues in either government or private industry. $\mathrm{He}$ demonstrates beyond a shadow of a doubt that Hezbollah has a global reach and is a national security threat to the U.S.

Mark Roberts, Transportation Security Specialist 